\title{
Reversed racism: fundamentalist genealogies in African-American religions ${ }^{1}$
}

\author{
Hans Gerald Hödl
}

As one of the consequences of the Atlantic slave trade, distinct religions evolved among the descendants of the Africans brought to the Americas. As a rule, Afro-Americans in Latin America developed their own religions (like Santería in Cuba or Candomblé in Brazil), based on West or Central African cultural matrices using elements taken from other traditions the slaves were exposed to, like Christianity and Spiritism. In contrast to Latin America, in North America under colonial rule and in ante-bellum USA there emerged, for the main part, evangelical forms of Christianity among the African Americans. In the class of those new religious groups outside mainstream Christianity that came into being amidst African Americans at the end of the $19^{\text {th }}$ and throughout the $20^{\text {th }}$ century, we find so called "messianic-nationalist sects" (Baer / Singer) that have in common a criticism of American society, a central myth about a glorious past of the "black race", and the strive to re-establish black supremacy in a golden future of the "black race". The mythical background concerning genealogies of races these religions share can be described as an inversion of white dualistic racist theories within the framework of Abrahamic religions: Dark skinned Africans are either regarded as the true Hebrews or as the true Muslims, "whites" as members of an inferior race. Some of these groups are openly separatist, whilst others have a more integrationist stance. This paper reads the development of some of these groups on the background of a sketch of African-American religious history and interprets it as a more or less fundamentalist reaction to a situation of incongruence.

Hans Gerald Hödl is a Professor at the Department of the Study of Religions at Vienna University. His research and teaching activities focus on Theory of Ritual, West African, Afro American and African American Religions, Mormonism and Critique of Religion.

1 I use the term "African-American" with reference to US citizens of African descent and the broader term "Afro-American" for inhabitants of the Americas stemming from Africa. 


\section{Got my Mojo Working: ${ }^{2}$ African Elements in Afro-American Religions}

Most Afro-Americans are the offspring of slaves that have been brought to the Americas during the transatlantic slave trade from the $16^{\text {th }}$ to the $19^{\text {th }}$ century c.e. Africans from different regions, mostly from West Africa and West Central Africa, have been subject to the so called triangular trade. ${ }^{3}$ They have also brought their religious traditions with them. But there is a remarkable difference between the way these traditions have influenced the development of Afro-American religions in the countries of former European colonies with catholic background and in those under predominant protestant rule. In the former countries, as a rule, more or less defined Afro-American religious bodies came into being, in which some features of Iberian Folk-Catholicism and $19^{\text {th }}$ century's Spiritism ${ }^{4}$ were put into the framework of (mostly: West, but also Central [Kongo]) African cultural heritage, ${ }^{5}$ so that one can clearly establish a relationship of these religions with

2 "Got my Mojo Working" is a blues song composed by Preston Foster (a white US American actor) made famous by Muddy Waters (a black musician). "Mojo" is a loving charm of prominence in Louisiana conjure and "Hoodoo". According to Long 2001, p. 82, "Robert Farris Thompson traces mojo to the word mooyo, by which the Kongo people mean the indwelling spirit of a charm". Alas, I could not find that passage on pp. 105 and 117 of Thompson's book "Flash of the Spirit", as cited by Long in note 20 on p. 280 of her work (although I found a reference to "toby" on p. 105, according to Long' $\mathrm{s}$ quotation). Neither "mo(o)yo" nor "mojo" are listed in the index of Thompson's book ("toby" is listed, under the category "charms", p. 305).

3 The Trans-Atlantic slave trade originated at the beginning of the $16^{\text {th }}$ century and increased steadily until the $18^{\text {th }}$ century, during which an estimated total of $6,494,600$ Africans have been sold into slavery in the Atlantic trade (for numbers, see Lovejoy 2013, pp. 46-50). Although slave trade began to be prohibited by European states and the USA since the beginning of the $19^{\text {th }}$ century (Lovejoy 2013, p. 135), there has been trade in slaves from Africa to the Americas until 1866 (with a total number of 3,873,600 African slaves exported from 1801 to 1866; see Lovejoy 2013, p. 141), named "the largest human migration to date" by Lovejoy 2013, p. 135. The Trans-Atlantic slave trade outnumbered the Muslim slave trade across the Sahara, the Red Sea and the Indian Ocean during that time (approx. 3,000,000 Africans from 1500-1800; see Lovejoy 2013, p. 68). For a short overview on the Atlantic slave trade see Collins / Burns 2014, pp. 212-226.

4 On these transformations in Cuban Santería see Hödl 2010.

5 The Yorùbá kingdom of Oyọ, which gained wealth through its involvement in the slave trade (like the neighbouring West African kingdom of Dahomey) seems to have started taking the supply of slaves from within at the beginning of the $19^{\text {th }}$ century, at which time its power also began to weaken until its fall in the era of approx. 1823-1836 (Law 1991, pp. 296-298; 307-308). This might have had an effect on the dominance of Yorùbá traditions among Afro-American religions in Latin America. According to Lovejoy, the slaves exported from the Bight of Benin during that time "were heavily 
(West and Central) African religious traditions. ${ }^{6}$ Furthermore, there is an exchange going on between some members of those religions and contemporary West African cults ${ }^{7}$ sharing those origins, and these Afro-American traditions are now open for members of non-African descent. Those Afro-Americans and African-Americans who embrace these religions, such as Santería and Candomblé, look to the African continent, mostly to West African peoples like the Yorùbá, the Ewe and the Fon or to KiKongo-speaking peoples ${ }^{8}$ as their progenitors. ${ }^{9}$ Furthermore, in the course of the $20^{\text {th }}$ and $21^{\text {st }}$ centuries, some of these religions have developed to players among religions of the world that are attractive for white Latin- and US-Americans as well as for Europeans. In this vein, they have also been interpreted as a contribution that Africa has made to the landscape of the world's religions today. ${ }^{10}$

The sole distinct Afro-American religious tradition that came into being in North America seems to have been the practice of "Voodoo" or "Hoodoo" in Louisiana. ${ }^{11}$ Zora Hurston held that this practice was brought there by slaves who

Yoruba in origin" (2013, p. 142); nevertheless, the total number of slaves taken from West Central Africa between 1801 and 1866 was nearly 5 times the number of those taken from the Bight of Benin (Lovejoy 2013, p. 141).

6 Literature on that topic is abundant; as this article focusses on North America, it cannot be discussed here in any detail. A precise description of the development of Cuban Santería can be found in Brown 2003. It captures both transmission of African Elements and construction of an African past (see especially chapters 2\&3, pp. 62-162); for Yorùbá elements in Brazilian Candomblé, see, e. g., Smith Omari-Tunkara 2005. Although many scholars stress the Yorùbá elements in these traditions, there are also elements from other traditions to be found, e.g., Fon, Ewe and Kongo.

7 I use the term "cult" here in a neutral way referring to organized groups of worshippers of different deities or of divination practices (like in "cultic milieu"), not as a derogatory term (like in "anti-cult-movement").

8 For the origins of slaves in the Trans-Atlantic trade - the greater part of which was taken from West Central Africa as a single supplier and West Africa from Senegambia to the Bight of Biafra - see Lovejoy 2013, pp. 45-61.

9 This way, the process of cultural and religious transformation that had characterized the development of the religious traditions in question has led to new forms of cultural exchange: citizens of "New World" countries travel to West Africa to be initiated into one of the traditional or neo-traditional cults there. An example would be Oba Efuntola Oseijeman Adelabu Adefunmi (1928-2005), born Walter Eugene King, the first African-American to be initiated into Santería (in 1959). He founded Oyotunji African Village in Sheldon, South Carolina, in 1970 and travelled to Nigeria in 1972 where he was initiated into the Ifá divination system (see Clarke 2009; on Adefunmi, ibid., p. 293). 10 For the tradition of Santería in the USA see, f. e., De la Torre 2004. Karade 1994 interprets Yorùbá traditions as one of the great religious traditions of the world, and, e. g., parallels certain Orisha with the 7 chakras of the Yogic tradition (ibid., pp. 38-46).

11 There is much debate about the terminology. "Voodoo" stems from the Fon word 
had come with their masters from Haiti after the Haitian revolution at the beginning of the $19^{\text {th }}$ century ${ }_{1}^{12}$ whilst Carolyn Long thinks that during the French rule in Louisiana African slaves - as in other Catholic colonies - might have stuck to their African religious rites in the free time granted them by the "code noir"13 and remarks that as an effect of the influx of immigrants to the then US-American state in the aftermath of the Haitian revolution, already existing Creole traditions had been fostered. ${ }^{14}$ There are some reports on this practice in which a small number of Gods can be identified as stemming from the Fon and Ewe people (whose traditions have strongly influenced Haitian Vodou) ${ }^{15}$ and there has been a famous Voodoo Queen in New Orleans, Marie Laveau. ${ }^{16}$ Today, we do not find these Afro-American cults ${ }^{17}$ in the southern states of the USA any more, with the exception of those imported from Cuba and other islands in the Caribbean during the $20^{\text {th }}$ century. African traditions per se have only survived in the realm of folk medicine, conjure, and magic, like in the case of the famous mojo, a love charm prepared by hoodoo doctors. ${ }^{18}$ Although there is a debate among scholars whether African elements have been preserved in African-American cultural

\footnotetext{
"Vodu(n)", which has two meanings: 1 . a religious practice; 2 . the supernatural beings adherents to this religious practice communicate with. The etymology of the word is debated (see Preston-Blier 1995, pp. 38-41). In Haiti, out of this tradition there evolved the Afro-American religion of Vodou (or "Vaudou"); the term "Voodoo" (as propagated as a negative stereotype in the film industry; see Sulikowksi 1996) is frequently used for a body of superstitious beliefs. As a rule, scholars of Haitian Vodou therefore do not use this term, as, e.g. Desmangles 2001, p. 361, who distinguishes between "Voodoo" (negative stereotype) and "Vodou" (the actual religion practised in Haiti). Anderson (in his entries on Hoodoo and Voodoo in Pinn 2009), distinguishes between the religious systems of Haitian Vodun and Mississippi Valley Voodoo (Anderson 2009b, p. 427), and between "Voodoo" as religion and "Hoodoo" as supernaturalism (related to conjure and magic; Anderson 2009a, p. 197).

12 Hurston 1931, p. 318: “[...] the Negroes fleeing Hayti and Santo Domingo brought to New Orleans and Louisiana, African rituals long since lost to their continental brothers". At least it was not the blacks that fled the Island of Saint Domingue, it was rather their white (French) masters who brought them along as their slaves.

13 Long 2007, pp. 10-12.

14 "The arrival of the immigrants from Saint Domingue, so similar in culture to the native New Orleanians, lifted Creole spirits and added reinforcements to the face of Anglo-American aggressiveness" (Long 2007, p. 29).

15 A synopsis is given by Long 2007, pp. 115-116; see also Anderson 2009b, pp. 433 f.

16 There is much of myth and legend surrounding that historical figure. Long 2007 is a thoroughly researched book doing away with most of the myths, e.g. that the "second" Marie Laveau (if she existed), who allegedly had secretly replaced the first when the latter grew old was a daughter or granddaughter of the first (ibid., pp. 190-205).

17 On my use of the term "cult" see footnote 7 above.

18 For "mojo", see footnote 2 above. On "Hoodoo" see footnote 11.
} 
traditions $^{19}$ (f.e., to which extent African-American music has its roots in West African music or is an adaptation of European music),${ }^{20}$ there are special forms of religious expression found in African-American Christianity that can be labelled as "African": The style of singing (call and response), dancing, clapping of hands, the style of preaching and ecstatic experiences of the spirit. Here we can find a form of Christianity using African ways of religious experience, whilst AfroAmerican religions in Brazil or Cuba (Candomblé, Santería) are transformations of African cults that make use of Christian iconography, spiritist practices and the like. Ecstatic phenomena like trance in African-American Christianity are interpreted as experience of the Holy Ghost, whilst in Santería, Candomblé and Haitian Vaudou media are possessed by distinctive deities, like Yemayá, Shango, Ogun and others.

\section{Go down Moses}

I now turn to a sketch of the development of "Slave Religion" in the USA. Although the Anglican Church had been interested in converting the slaves to Christianity, in colonial times, slave owners were reluctant to having their slaves baptized, mostly for the fear of emancipation as a consequence of being Christian. ${ }^{21}$ Anglican preachers therefore tried to show that there is no contradiction to the bible in having fellow Christians enslaved. ${ }^{22}$ In contradistinction to the Catholic practice, Anglican clergy furthermore relied on catechizing before baptism, aiming at converting the African-Americans by instructing them in the Christian faith. ${ }^{23}$ They were less successful than those revivalist denominations that entered the scene in the $18^{\text {th }}$ century, like Baptists and Methodists, who stressed the conversion experience. ${ }^{24}$

The root of black mainstream churches in the USA lies in Evangelicalism ${ }^{25}$ and this way Evangelicalism seems also to have been influenced by African-Ameri-

19 The debate centred on Melville Herskovits' "The Myth of the Negro Past" (1941). It is described and discussed, e. g. in Raboteau 1978, pp. 48-55.

20 For an overview on positions held in this discussion see Cone 1991, pp. 9-12.

21 Raboteau 1994, p. 2; 1978, pp. 97-103.

22 Raboteau 1994, p. 3; 1978, pp. 103; 122-124.

23 Raboteau 1978, p. 115.

24 Raboteau 1994, p. 4; 1978, pp. 132-134. The first to have stated this seems to have been Robert E. Park: "It was not, however, until the coming of the new, free and evangelistic types of Christianity, the Baptists and the Methodists, that the masses of the black people, that is, the plantation Negroes, found a form of Christianity that they could make their own" (Park 1919, p. 119; see also Frazier 1940, p. 31).

25 "Soon after the revivals began in the southern colonies, powerful black preachers [...] began to spread evangelical Christianity to fellow African Americans [...]." (Kidd 2007, p. 214; see also MacRobert 1997, pp. 300 f.). 
cans. Different missionary strategies ${ }^{26}$ are not the only factor that has played a role in different developments of Afro-American religions in Latin America and North America: ${ }^{27}$ A much smaller number of slaves had been brought to the North American colonies than to those in Latin America. The number of slaves owned by North American farmers was also smaller than the number of slaves on plantations in Latin America. This circumstance might have had an effect on the process of acculturation. There was a balance of female and male slaves that differed from the situation in Latin America, where the number of male slaves was higher. In North America, most slaves were born on the continent as the offspring of formerly enslaved Africans, whilst in the Caribbean and in Brazil there was a steady supply of new slaves taken from Africa replacing those who had died. This way, the traditions of those peoples whose members had been enslaved at the end of the transatlantic slave-trade have had a greater impact on the Afro-American traditions in Latin America, and there was a steady influx of people who had a clear memory of their African homeland, culture and religion. In North America, the picture of the African homeland grew fainter with every new generation born on the continent.

No sooner than at the beginning of the $19^{\text {th }}$ century black slaves in antebellum south had significant religious institutions of their own (African churches). ${ }^{28}$ They either attended church together with their white masters or under white supervision. ${ }^{29}$ Nevertheless they had their own religious practices, often clandestinely conducted at night time - their form of "invisible religion". ${ }^{30}$ The singing of the so-

26 As Raboteau points out, "American Evangelical Protestantism [...] was not as conductive to syncretism with African theology and ritual" [as Catholicism; author] (Raboteau 1978, p. 88). It has to be noted, that in recent research on Afro-American religions the term "syncretism" has been dismissed as an apt description of the process in question; see, e.g., Brandon 1997, pp. 157-185, who does a deconstruction of the term, rendering it as a "black-box-concept" (p. 181), which has no explanatory value.

27 For the demographic factors rendered here, see Raboteau 1978, pp. 89-92.

28 The first African American Baptist Congregation was founded in in 1760 in Virginia according to Pinn 2009c, p. 616, whilst Raboteau (1978, p. 139) and Baer / Singer 2002, p. 15 (who quote Raboteau) maintain that the Silver Bluff Church (founded between 1773 and 1775) "was the earliest black Baptist church in North America". Nevertheless, there have been black Baptist congregations (often suppressed) among blacks before the first white Baptist congregations sprung up (Raboteau 1978, 137). The first African Methodist Churches that came into existence at the end of the $18^{\text {th }}$ century were restricted to the North (Baer / Singer 2002, p. 17).

29 An overview is given by Baer / Singer 2001, pp. 10-14. On the one hand, slave owners were reluctant to having their slaves baptized (see Raboteau 1978, p. 106) or attending church together with them (ibid., pp. $102 \mathrm{f}$.). On the other hand, blacks were sometimes ridiculed by their fellow slaves, when having converted (Raboteau 1978, p. 121).

30 A detailed description of these practices is given by Raboteau 1978, pp. 212-288. 
called spirituals was central among these distinctive practices of African-American Christians in the antebellum south. Initially, spirituals have been sung out collectively in the course of a ring-dance that has been called "the shout". This means, that they have not only been sung, but acted out. In the words of Albert J. Raboteau:

The shout would start with a leader calling out a verse of a spiritual while the shouters responded by walking around in a circle. When the singers who stood outside the ring took up the chorus, the shout proper would begin with the ring band shuffling rapidly to the beat announced by the hand-clapping and foot-tapping of the chorus of singers who were said then to be "basing" the shouters. ${ }^{31}$

The lyrics drew from the bible and the protestant hymn book, and so they were mostly made up of biblical imagery and stories. In the course of the "shout" - that could last for hours - communication or exchange took place between the individual's experience that would be coded by the special meaning the words of the spiritual had for his or her situation, and the community. ${ }^{32}$ So, the biblical stories and images could be used by the individual to reflect his or her situation. ${ }^{33}$ That way, many layers of meaning would be developed, and biblical places and figures could be used to reflect the situation of the slaves and to express their hopes. Among these stories, the most important was the story of Exodus. ${ }^{34}$ As one white army chaplain has noted:

There is no part of the Bible with which they are so familiar as the story of the deliverance of Israel. Moses is their "ideal" of all that is high, and noble, and perfect, in man. I think they have been accustomed to regard Christ not so much in the light of a spiritual deliverer, as that of a second Moses who would eventually lead them out of their prisonhouse of bondage. ${ }^{35}$

This reverses the use of the story by European settlers in North America, who have thought of their journey from Europe to the New World as a new Exodus

31 Raboteau 1978, p. 245.

32 Furthermore, as Lawrence Levine has remarked, "the slaves created a new world" (quoted by Chireau 2000, p. 19) and, as Chireau (ibid.) has put it, in "these moments of transcendence, the boundaries between sacred and profane were effaced, as black worshippers dramatized pivotal events in early Jewish history" (maybe those pivotal events would better be rendered as belonging to "myth" than "history"). According to Levine 1997, pp. 74-75, "The slave's 'shout' [...] often became a medium through which the ecstatic dancers were transformed into actual participants in historic actions [...]".

33 Raboteau 1978, pp. 246 f.

34 See, e.g. Fulop 1997, p. 230: "Of particular importance in African-American thought is the biblical story of the Exodus and the image of Canaan".

35 Raboteau 1978, pp. 311 f.; 1994, p. 13. 
from Egypt to the Promised Land. For their African slaves, America meant Egypt, where they were held in bondage under a New Pharaoh. ${ }^{36}$ The story of Exodus served as a vision of a better future for the slaves on the one hand. ${ }^{37}$ On the other hand it symbolized the common history of the African-Americans and fostered their feeling of being one people. As Albert J. Raboteau has remarked, this metaphorical use of the biblical story became a literal reality when it was acted out during the ring dance: "In the ecstasy of worship, time and distance collapsed, and the slaves literally became the children of Israel [...] travelled [...] through the Red Sea [...] saw Pharaohs army 'get drowned', [...] crossed Jordan under Joshua and marched [...] around the walls of Jericho." ${ }^{38}$

This way, the religious metaphors we know from the so called Spirituals had a very concrete place in the lives of the African-American population. Crossing the river Jordan was not only understood symbolically or as a re-enactment of an old story, but also literally as crossing the border to the North and to emancipation. ${ }^{39}$ The land of "Canaan" was a schibboleth for the North or Canada. The reading of the story by the African-Americans also inverted the use of the biblical narrative by the white slave-holders. One special argument for the inferiority of people of black colour and the right to hold them in slavery was the biblical story of the curse of Ham's son Canaan, as Africans of dark skin were thought to be the offspring of Ham. ${ }^{40}$ Some preachers of black millennialism, as it flourished as a reaction to the so called "Nadir" descendants of Shem, Africa to the descendants of Ham and Europe to the sons of Japheth, looking at America as the nation where those race boundaries would be overcome. ${ }^{42}$ Others, aptly called Millennial Ethiopianists, looked for Africa as the continent of a Black Millennium. ${ }^{43}$ As we have already seen, black slaves used to identify with Old Israel in a more or less metaphorical way. In still another reading of the biblical story, some claimed, that since Ham was black, it followed that most

36 Raboteau, 1994, p. 9; 1997, p. 101.

37 For "God as Liberator" in the lyrics of the spirituals, see Cone 1991, pp. 32-43. At the beginning of this chapter, he sums it up as follows: "The divine liberation of the oppressed from slavery is the central theological concept in the black spirituals" (p. 32).

38 Raboteau 1994, pp. $13 \mathrm{f}$.

39 Ibid., p. 14.

40 Gen 9,18-29; in former times, the Afro-Asiatic languages were classified as Semito-Hamitic.

41 A term in use for the last 25 years of the $19^{\text {th }}$ century in African-American history, a period of an attitude of whites against blacks looking at them as an inferior race, of disenfranchisement and lynching (see Fulop 1997, p. 230).

42 Fulop 1997, pp. 232-234.

43 Ibid., p. 231, characterises Millennial Ethiopianism as a doctrine that "posits a panAfrican millennium, a future golden age continuous with a glorious African past accompanied by God's judgement of white society and Western civilization". 
people of the Ancient Near East were black and therefore black people played a significant role in history.

\section{3. "Jesus Christ was black" $" 44$}

We can take this adaptation of biblical genealogies as a forerunner of one peculiar message some African-American preachers spread at the beginning of the $20^{\text {th }}$ century: That the African-Americans were descendants of the Israelites. ${ }^{45}$ At the time this doctrine arose, a migration of African-Americans from the rural south to the urban north took place, ${ }^{46}$ in the context of which non-Christian black nationalist religious movements came into being that have been classified by Baer and Singer as "messianic-nationalist sects" ${ }^{47}$ using a sociological typology loosely oriented at the classic church-sect paradigm as developed by Roy Wallis. ${ }^{48}$

These typologies use two criteria that can have two biases (yes/no) and therefore can be combined in four ways. The criteria used by Baer and Singer are modelled after the basic idea to distinguish the interaction of the religious groups in question with the larger society. ${ }^{49}$ Baer and Singer do not engage in the discussion of how to delineate between church and sect, denomination and cult in the

44 KRS-One (Lawrence Parker); from "The Eye Opener" the third track on the 1991 album "Live Hardcore Worldwide" by the Hip-Hop-Group Boogie Down Productions. In 2009, KRS-One published a 600 pages book, called "The Gospel of Hip-Hop: The First Instrument". On his homepage "The Temple of Hip-Hop" he writes about that book: "The Gospel of Hip Hop is a uniquely written instrument designed to guide a new generation of Hiphoppas spiritually and establish the groundwork for a new Hip Hop nation. More of a reference and teaching aide, The Gospel of Hip Hop lays out a practical approach to the spiritual living of Hip Hop." (http://www.krsone.biz/temple_bio.html last accessed on January 29, 2016).

45 This background is consensually acknowledged among the authors writing on Black Hebrews; see, e. g. Chireau 2000, pp. 17-20; Fernheimer 2009, p. 170; Brotz 1970, pp. $6 \mathrm{f}$.

46 Baer/Singer 2002, p. 114; they remark, that black nationalism "did not appear sui generis with the migration" and shortly point to the themes of liberation in AfricanAmerican Christianity and its interpretation of the myth of Exodus outlined above. Fauset 2001, pp. $7 \mathrm{f}$, , also names the migration to the north as a relevant factor in the emergence of Black Nationalist religious groups.

47 The main characteristics of these "sects" are "belief in a glorious black past" that has been lost, "opposition and criticism to American culture and whites", "anticipation of divine retribution against the white oppressor", "assertion of black sovereignty", and "chiliastic and messianic expectations of a new golden age for black people" (Baer / Singer 2002, p. 56).

48 Wallis, 1976, pp. $12 \mathrm{f}$.

49 Baer / Singer 2002, pp. 52-54, diagram on p. 55. 
descriptive use sociologists of religion make of those terms. ${ }^{50}$ In their opinion, all African-American religious organisations are in tension with the larger society and therefore can aptly be called sects. ${ }^{51}$ They distinguish between a positive and a negative stance towards society, positive meaning a basic agreement with the principles the society rests upon, negative being characterized by rejecting the prevalent values or being repulsed by them. Furthermore, they distinguish between an active and a passive mode of social action. In this typology, messianicnationalist sects are characterized by a rejection of the dominant society and take social actions in order to pursue their goal of overthrowing the actual order of things. ${ }^{52}$ The main religious movements grouped here fall into two categories: Black Judaism and Black Muslims. ${ }^{53}$

I will first give an overview on Black Hebrew groups here and then turn to a discussion of the Nation of Islam in part 4 of this essay, in order to point out similarities and differences in their respective constructions of "race". As a rule, Black Hebrews are (or have been) smaller groups than Black Muslim organisations. The term is used for a broad spectrum of religious organisations and individuals, ranging from those who are accepted by official Judaism, either because of stemming from a Jewish mother or because of having converted according to halachic rules to those who claim that African-Americans are the offspring of the ancient Israelites. ${ }^{54}$ Some of the latter groups are rather syncretistic, in mixing Judaic and Christian elements in their worship. They consequently hold that Jesus Christ was black. ${ }^{55}$ All of them claim that African-Americans are the offspring of Jews, either the lost tribes or the tribe of Judah. Some of them - notably Rabbi Wentworth A. Matthew of the Commandment Keepers of Harlem - traced their origin to Beta Israel, the Ethiopian Jews. ${ }^{56}$ This genealogy has its roots in the idea

50 At least in the German speaking world, in Religious Studies the descriptive use of the category "sect" has been dismissed; see Remus 2005.

51 Baer / Singer 2002, p. 54.

52 "Central to the vitalizing core of these groups is a fundamental critique of the place and treatment of people of African heritage in American society. Implied in this critique and often expressed outright is a rejection of the accommodationist features found in other African American religious organisations" (Baer / Singer 2002, p. 113).

53 Baer/Singer 2002, p. 113; against the idea, that with respect to tensions between Judaism and the Muslim world, "lumping black Muslims and black Jews into a common pool might appear reckless", they argue, that both types of messianic-nationalist sects share a common "heritage and a basic belief structure, articulated through [...] differing religious symbol systems" (ibid.).

54 Fernheimer 2009, p. 170.

55 As the Church of the Living God of Prophet Cherry does: Fauset 2001, p. 34; Pinn 2009a, pp. $167 \mathrm{f}$.

56 Brotz 1970, p. 15; Brotz 1970, pp. 19-22 reprints the construction of the origin of races based on biblical genealogy from "a small handbook for Members" by Rabbi 
that Ethiopia was the homeland of African-Americans. ${ }^{57}$ Out of this idea, attempts of repatriation resulted, as propagated by Marcus Garvey's Universal Negro Improvement Association, best known for its influence on the Rastafari movement. ${ }^{58}$ According to Singer and Baer, the so called Ethiopian affair of 1920 was the first occasion on which the existence "of a militant, messianic-nationalist brand of black Judaism" "59 came to be noted by the wider public. During a parade organised by an offspring of UNIA, two American flags were burned which led to

Wentworth, titled "The Anthropology of the Ethiopian Hebrews and their Relationship to the Fairer Jews".

57 As Barrett 1997, p. 75 has put it, Africa as a geographical entity "was [...] obliterated" from the memory of the African-Americans by the time Black Churches came into existence in the USA: "Their only vision of a homeland was the biblical Ethiopia". So Ethiopia became a schibboleth for the African homeland, and the so-called "Ethiopianism" came into being. The feeling of being "one people" that grew out of a shared experience of the African-Americans (who were indeed of mixed African descent) had as its counterpart the "white" other (who indeed represented a group of mixed European descent). On the one hand, this led to the emergence of separate "black" institutions. Seen from the "other's side", white ministers at the beginning of the $19^{\text {th }}$ century started to state demarcations drawn by God between blacks and whites (see Smith 1998, p. 535). In this vein, the first society that was founded in the USA with the aim of repatriation of freed Afro-Americans was the "American Colonization Society "(ASC, founded in 1816; Smith 1998, pp. 535 f.). This anti-integrationist stance was later shared by black proponents of emigrationalism in the service of ASC, like Edward Wylmot Blyden, who, e. g., asked the ASC in 1870 to only send "pure Negroes" to West Africa (Curtis 2002, p. 34). Black emigrationist initiatives of the $20^{\text {th }}$ century have emerged in the time of colonialism. With the exception of Liberia (which was not a colony, but under US control), Ethiopia was the only African country at the turn of the centuries not under European colonial rule. Together with its biblical status, this made it the perfect goal for repatriationists holding the idea that African-Americans would "return to Africa to redeem the continent from colonialism" (Smith 1998, p. 537). On the religious side, "Ethiopia" became the dwelling place of God Almighty, as Garvey remarked: "We Negroes believe in the God of Ethiopia, the everlasting God-God the Son, God the Holy Ghost, the one God of all ages. That is the God in whom we believe, but we shall worship him through the spectacles of Ethiopia" (quoted in Barrett 1997, p. 77).

58 Arnold Josiah Ford, who was a main influence on Matthew, was a leading member of the UNIA and its musical director. Having hoped that Judaism became the religion of the UNIA, he was somewhat disappointed, when the African Orthodox Church of Bishop McGuire became the main religious influence in Garvey's organisation. He emigrated to Ethiopia in 1930, where he died in 1934 without fulfilling his vision of building a Black Jewish colony (Vincent 2006, pp. 116 f.; 184; see also Chireau 2000, p. 26). On Garveyism and Rastafari see Barrett 1997, pp.76-84; Chevannes 1998, pp. 10 f.; Vincent 2006, pp. 189 f.

59 Baer/ Singer 2002, p. 115. 
a shooting in which two men were killed. Grover Cleveland Redding, who was convicted for murder, claimed to be of Abyssinian royal ancestry.

Black Hebrews either look at Ashkenazim and Sephardim as resulting from racial mixture or as impostors. Frank S. Cherry, the founder of the Church of the Living God, Pillar of Truth for all Nations, held the latter idea ${ }^{60} \mathrm{~A}$ former railroad worker, he began to preach in the early 1880ies that black Americans were the true Jews. ${ }^{61}$ He moved from Chattanooga, Tennessee to Philadelphia, where one small community of his church is still in existence. ${ }^{62}$ According to him, people of white skin are the offspring of the servant of the prophet Elisha, Gehazi ${ }^{63}$ who was punished with leprosy for his misbehaviour, according to 2 Kings, 5: 20-27, the most important verse being 27 when Elisha says to Gehazi: "Naaman's leprosy will cling to you and to your descendants forever." It continues: "Then Gehazi went from Elisha's presence and his skin was leprous - it had become as white as snow."

Apparently, this is a counter-story to the idea held by white slaveholders that black Africans were the offspring of Noah's grandson Canaan. In both stories not only a person, but also his descendants are cursed. Because of a wrong etymology of the name "Ham" the curse of Noah became connected to black skin, although in Genesis 9 skin colour is not mentioned. The myth solely explains the subordination of the Canaanites to the Israelites. According to Cherry's use of the story from 2 Kings, the original Israelites were black, and Caucasian Jews are a fraud. ${ }^{64}$

Another Black Hebrew church founded at the end of the $19^{\text {th }}$ century is The Church of God and Saints of Christ. William Sanders Crowdy (1847-1908), a freed slave, began to preach because of visions and auditions he received, in which God commanded him to do so. ${ }^{65}$ According to him, African-Americans were members

60 On Cherry - on whose early life no ascertained information does exist - see Fauset 2001, pp. 32 f.; Pinn 2009a, p. 167; Baer / Singer 2002, pp. 115 f.; other groups that hold this view are The Nubian Islaamic [sic!] Hebrews (see O'Connor 2000, pp. 122 f.) and the Nation of Yahweh (see footnote 69).

61 According to Singer 2000, p. 28, Cherry founded his church in 1886; Pinn 2009a, p. 167, writes that Cherry organized the Church of the Living God in 1866. Given that Cherry died in 1965, this is rather unlikely; it seems to be a typo.

62 According to my research on the internet, there is only this one community left. Another church of a similar name, a Pentecostal denomination called "House of God, which is the Church of the Living God, Pillar and Ground of the Truth, Inc." was founded in 1903 by Mother Mary Magdalena Lewis Tate (1871-1930). On Tate, "the first woman in the United States to head a predominantly black denomination as chief overseer and bishop" (Hardy 2007, p. 747), see Hardy 2007, pp. 747-750.

63 Baer/ Singer 2002, p. 116.

64 Fauset 2001, pp. $34 \mathrm{f}$.

65 On Crowdy, see Wynia 1998, pp. 19-28; Singer 2000, pp. 58-60; Baer / Singer 2002, p. 166; Pinn 2009b, pp. 152-154. 
of the lost tribes, Jews were originally of black skin and the "caucasian" Jews were an offspring of intermarriage between Jews and "Caucasians". ${ }^{66}$ After his death, the church developed into a syncretistic church merging elements taken from Judaism, Christianity and Free-Masonry. ${ }^{67}$ According to its homepage, the church actually has 37 "tabernacles" in 4 districts in the USA, 1 in Kingston, Jamaica, and several tabernacles in 7 districts on the southern part of the African continent, mostly in South Africa, but also in Malawi, Swaziland and Zimbabwe. ${ }^{68}$

There are also Black Hebrew movements that propagate repatriation of Black Jews in Israel, like the Nation of Yahweh ${ }^{69}$ that could not reach this goal, in contradistinction to the movement founded by Ben Carter (1939-2014) who took the name Ben Ammi Ben Israel when joining a Chicago based Black Hebrew group. ${ }^{70} \mathrm{He}$ claimed to have had a vision in which the Archangel Gabriel told him, that he was the chosen leader "to lead the true African Israelites back to the promised land". In 1966 he managed to emigrate with 300 of his followers to Liberia, later to Israel, where the community of approx. 1500 members lives in a settlement in the town of Dimona (Negev). ${ }^{71}$ On December 27, 2014, Ben Ammi died. ${ }^{72} \mathrm{He}$ had been referred to as "abba" by the members of the group, the fate of which seems to be uncertain after the death of its charismatic leader. The community has a vegan diet, called "Edemic" (from "the garden of Eden"), observes Sabbath from Friday to Saturday and sticks to biblical rules on menstruation (niddah). Some men practice polygamy, due to their interpretation of biblical texts. ${ }^{73}$ Initially, Ben Ammi had denied the legitimacy of white-skinned Jews, in an interview in 1996 he said that his experience in Israel had changed these views and

$66 \quad$ Singer 2002, p. 59.

67 Singer / Baer 2000, p. 116.

68 http://cogasoc.org/wordpress/locations last accessed on January 29, 2016.

69 This movement was founded by Hulen Mitchell Jr. (1935-2007), the first of 15 children of a Pentecostal preacher, who came to be convinced of his Godly nature at a young age and later changed his name to Yahweh ben Yahweh ("Lord Son of the Lord"). Having successfully established his church that grew to be the biggest among Black Hebrew denominations, the further development of the movement was somehow obstructed, when Ben Yahweh was charged for conspiracy on the murder of 12 whites in 1990. He was released from prison in 2001. His faithful followers interpreted his imprisonment as a parallel to the crucifixion of the Christ (see: http://www.yahwehbe nyahweh.com/ last accessed on January 30, 2016). On Hullen and his movement, see Easterling 2009, p. 113.

70 On Ben Ammi see Easterling 2009a, p. 112; Michaeli 2000.

71 A detailed description of this migration is given by Singer 2000, pp. 60-69; see also Michaeli 2000, pp. 73-75 and Easterling, 2009a, p. 112.

72 http://www.nytimes.com/2015/01/01/world/middleeast/ben-ammi-ben-israel-leaderof-black-americans-who-migrated-to-israel-dies-at-75.html?_r=0 last accessed on January 30, 2016.

73 Michaeli 2000, pp. $75 \mathrm{f}$. 
he now would include some Jews among the chosen people. ${ }^{74}$ This way, he seems to have abandoned the idea that some of the more radical Black Hebrews hold. Whilst most think that European Jews are not the original Jews (that stem from Ethiopia), but converts, the more radical version sees European Jews as intruders on the original covenant, and white people as evil and led by Satan. ${ }^{75}$ This idea stems from the conviction that the white race as such is evil and under Satan's leadership.

\section{Fear of Black Planet ${ }^{76}$}

The idea that the white race is evil per se has also - and notoriously - been propagated by the Nation of Islam, which I use here as an example for nationalist Black Muslim movements. I will give a short overview of the group's history and core teachings in order to compare the race construction and the reading of the biblical narrative of this group with the beliefs held by those discussed above. NOI can trace its roots back to the Moorish Science Temple founded by Nobel Drew Ali (Timothy Drew, 1886-1929) ${ }^{77}$ in $1913^{78}$ in Newark, New Jersey. ${ }^{79}$ Legend has it

74 Michaeli 2000, p. 81; in a similar way, Elijah Mohammed changed his views that Jews as a subset of Whites are devils in "How to eat to Live" to a more friendly attitude against orthodox Jews (Deutsch 2000; pp. 94 f.; 97 f.).

75 Easterling 2009a, p. 114.

76 "Fear of a Black Planet" is the $3^{\text {rd }}$ studio album by hip-hop group Public Enemy, who have praised Nation of Islam leader Louis Farrakhan on the track "Bring the Noise" from their second album "It Takes a Nation of Millions to Hold Us Back" ("Farrakhan is a prophet and I think you ought to listen to. What he can say to you. What you ought to do") and have been acknowledged by him when inducted to the "Rock and Roll Hall of Fame": http://www.finalcall.com/artman/publish/Entertainment_News_5/article_9921. shtml, last accessed April 23, 2016.

77 On Drew and the Moorish Science Temple see Curtis 2002, pp. 45-62; Easterling 2009b; Baer / Singer 2002, pp. 121-123; Curtis 2014, pp. 147 f.; Lincoln 1961, pp. 50-55; Fauset 2002, pp. 41-51.

78 Curtis 2002, p. 47, remarks on the validity of this date: "Every scholarly source of which I am aware lists the date of the founding of the MST as 1913, though none of these sources produces any evidence for this date except references to other secondary sources or oral history interviews with movement members".

79 Some other Black Muslim institutions have also been founded in the first decades of the $20^{\text {th }}$ century in the USA, by the Ahmadiyya Sufi order (that was also of great influence on the spread of Islam in West Africa at this time; see Stewart 1986, pp. 216217) and Sunni traditions in which African missionaries were important (Curtis 2014, pp. 146-147). The Ahmadiyya movement stems from Punjab, India, and initially claimed that "Ghulam Ahmad was both the messiah of Jewish, Christian, and Islamic tradition and the Islamic Mahdi" (Curtis, 2006, pp. 46-47). The movement split, and the one 
that the man travelled extensively in North Africa and the Near East, where he received training by prophets and sages and was introduced to Islam. He also claimed to have received the name "Noble Drew Ali" during that time. ${ }^{80}$ His teachings are a blend of elements taken from Islam, Christianity, Freemasonry, Theosophy and Pan-Africanism. Among his scriptures is the Holy Koran, a book composed mainly of passages taken from a theosophical text ("The Aquarian Gospel of Jesus Christ") and a Rosicrucian text ("Unto Thee I Grant" or "The Infinite Wisdom"). ${ }^{81}$ This way, his version of the Koran has almost nothing to do with the scripture revealed to Mohammad, but is a sample of esoteric texts. From his point of view, the Qur'an was Mohammad's translation of Old Egyptian Mysteries, in which Ali claimed to have been initiated. For him, Al-Islam is only a partial understanding of the original religion and Allah, whilst the Egyptian mysteries Ali claimed access to, are the oldest form of mankind's religion and the basis of all religions of the world. People of dark complexion he called Moors, and he taught that they have originated from the ancient peoples mentioned in the Bible. ${ }^{82}$ South-East and East Asian peoples as well as the Natives of the Americas he thought to be the descendants from the lineage of Hagar, mentioned in the Bible as Moabites, Canaanites, Hittites, Cushites and Hamites. Because of this connection to peoples mentioned in the Biblical Scriptures, these Asiatic peoples are also called Moorish by Ali. ${ }^{83}$

After the death of Nobel Drew Ali, one of his followers, Wallace D. Fard, a rather mysterious figure, claimed to be a reincarnation of Ali, which he also understood as a proclamation of his divinity. Working as a peddler in Detroit, he preached that the true religion was not Christianity but Islam and held some meetings, in which he used both the Qur'an and the Bible. He taught the white people were "blue eyed devils". ${ }^{84}$ After Fard's disappearance in 1934, Elijah Poole, who took the name "Elijah Muhammad" became the leader of the NOI that Fard had founded. He put the ideas of black supremacy and how the white man had usurped black dominion already preached by his predecessors into the framework of dispensationalism, an idea prominent among evangelical Christians. ${ }^{85}$ According to this doctrine, history is divided into several "dispensations",

section that held that Ahmad was but a renewer of religion and not a prophet was of influence on the NOI (Curtis 2006, p. 47).

80 Curtis 2002, p. 47.

81 As Curtis 2002, pp. 58-60 has shown.

82 Ibid., p. 54; Berg 2005, pp. $689 \mathrm{f}$.

83 These genealogies that rely on the Hamitic myth (Berg 2005, p. 690) are included in the last sections of The Holy Koran, Chapter XLV to XLVII; pp. 56-59; see also Curtis 2002 , p. 54

84 On Fard see Lincoln 1961, pp. 10-14; Baer / Singer 2002, pp. 123 f.; Mamiya 2009b, pp. $239 \mathrm{f}$.

85 On Dispensationalism in Black Christianity as an influence on Elijah Mohammed, 
historical periods in which God makes different covenants with mankind. The teaching of Elijah Muhammad has at its core, that earth was inhabited from very ancient times ( 66 trillion years) on by the black tribe of Shabazz and ruled by 24 scientists. 6000 years ago, a mad scientist by the name of Yakub created the white race, a devilish race. All the prophets God sent to the white race (among them Jesus and Mohammad, both of them black-skinned) could not succeed in converting them to the true religion of Islam. With the enslavement of African people by the white race, the millennium in which we now live began, and the time was ripe for the judgement of God and the retribution of the evil deeds of the white race. This age of retribution has begun with the appearance of Wallace D. Fard. ${ }^{86}$ Again, this myth makes reference to the biblical (hi)story:

These events and prophecies are recorded in the Bible according to Elijah Muhammad. For instance, the story of Adam and Eve in Genesis is the story of the creation of the white race, and the apocalypse in the Book of Revelation is the prophecy written by Yakub against the white race he created. ${ }^{87}$

In 1948, when serving a sentence in prison, Malcolm Little was introduced to the teachings of the NOI. As Lawrence Mamiya has put it, ${ }^{88}$ the doctrine of the white man being the devil along with the myth of Yakub served as a kind of theodicy and rationalization for Malcolm like for many other African-Americans. Exactly, it explained "[...] all of the pain and suffering inflicted upon black people in America. It all began to make sense: the chaos of the world behind prison bars became a cosmos, an ordered reality" ${ }^{\text {" }}$. After overcoming his drug-addiction and other personal problems, Malcolm became probably the most prominent figure in the history of NOI. He was named Malcom X, after the practice introduced by Elijah Muhammad of substituting the slave name of members of NOI by an X. The X meant "undetermined", an "unknown quantity" or ex-slave, ex-drinker, ex-Christian and the like..$^{90}$ After a period of faithfulness, a new name was given symbolising the change that had taken place within the person. Malcolm Little became "Mulik Shabazz". The dualistic world-view regarding race relationships made Malcolm X to an outspoken critic of the Civil Rights Movement led by Martin Luther King, who was the son of a Baptist minister, just like Malcom. The

see Curtis 2002, pp. 64-67. Dispensationalism is also featured in the teachings of F.S. Cherry, who held that God created the earth 6000 years ago and that every two thousand years there was a dispensation. He expected the return of Jesus and the millennium at the end of the $20^{\text {th }}$ century (Fauset 2001, p. 35).

86 For this "myth of Yakub" see Curtis 2002, pp. 74-76; Berg 2005, p. 692.

87 Berg 2005, pp. $692 \mathrm{f}$.

88 Mamiya 2009b, pp. $242 \mathrm{f}$.

89 Ibid., p. 242.

90 Ibid., p. 243. 
latter was striving for Black Nationalism in a separatist framework, whilst King was opting for racial equality in an integrationist one..$^{91}$

As NOI came under permanent critique by Islamic organisations for the form of Islam that it practiced, which had virtually nothing to do with Sunni or Shia Islam, Elijah Muhammad was criticised for his life style, ${ }^{92}$ and the separatist orientation of Muhammad led to a kind of collaboration with white racist groups, ${ }^{93}$ Malcolm, who first had defended Elijah Muhammad, began to study Sunni Islam, ${ }^{94}$ converted, and left the NOI ${ }^{95}$ He was murdered in $1965 .{ }^{96}$ After the death of Elijah Muhammad, who had stayed with his original teachings, obviously not able to adopt a more orthodox form of Al-Islam, his son Wallace Delaney Muhammad (as a family member) became his successor and not the prominent minister Louis Farrakhan. This led to a schism along the line that can be drawn between the understanding of Islam in classical NOI teaching and orthodox Sunni Islam. Wallace Muhammad reformed the group according to standards of orthodox Sunni Islam. The organisation under the leadership of Imam Muhammad had several names, among them the American Muslim Nation and the American Society of Muslims. ${ }^{97}$ Since 1977, the original NOI is led by Louis Farrakhan, who is often criticised for Antisemitism, but on the other hand has proven to be a charismatic leader and an organizer of nation-wide events for the AfricanAmerican community, in which far more than the members of NOI have been involved. NOI, and some of its offshoots, namely the Five Percent Nation, have had a significant influence on the hip-hop-scene. ${ }^{98}$

91 On the relationship of King and Malcolm X see Carson 2005.

92 On this critique, see Curtis 2002, pp. 79-83.

93 "Muhammad had sent Malcolm to Atlanta to meet with Ku Klux Klan officials to obtain the white supremacist group's support for the Nation's plan to create a separate black state (15). This meeting, which remained a well-kept secret until Malcolm's break with the Nation, was one of the factors that caused Malcolm to become increasingly sceptical of Muhammad's motives and integrity even before he learned of his mentor's infidelities" (Carson 2005, p. 24).

94 Under the guidance of an Egyptian Muslim scholar by the name of Mahmoud Youssef Shawarbi (Curtis 2002, pp. 91-93).

95 Curtis 2002, pp. 88-96.

96 So the question remains unanswered, whether the adoption of Sunni Islam would have led Malcolm to a more "integrationist" and less "nationalist" view of racial relations.

97 On Wallace D. Muhammad and his re-orientation of his father's religious organisation see Curtis 2002, pp. 107-127 and Mamiya 2009a.

98 An analysis of the presence of separatist or black supremacy discourse in popular African-American culture is outside the scope of this short overview. I have given but a few hints. 


\section{Conclusion}

I started this overview with a short comparison between the religious and cultural situation of Afro-Americans in Latin and North America. The circumstances of the slave trade have left those living under catholic rule with a more clear idea of their African origins, and therefore of their identity. It would be another task to investigate, how Afro-American religions in these countries have contributed to constructing ethnic identities among the slaves in correlation to the white "other". Be that as it may, the North American situation differed, out of various reasons mentioned: The African homeland became a faint idea there. African religious elements were rather preserved on the formal side of religious practice than as a content of it (e.g., an identifiable African Godhead). Being exposed to Christian mission, biblical stories (in the framework of history of salvation) became a medium for reflecting the situation of the slaves. The biblical stories of the enslavement of the Israelites and the way they gained freedom by the mythical process called Exodus, led to an identification of christened slaves with the Israelites, on a metaphorical, but also on a more literal level. Searching for an identity as opposed to the one ascribed to them by the slaveholders, AfricanAmericans developed different strategies. In this paper, I have only looked at the strategies used by the messianic-nationalist "sects" in the typology of Baer / Singer. ${ }^{99}$ Within the drawn examples of the religious groups put into this category by Baer and Singer, we have taken a look at some Black Hebrew and Black Muslim organisations. Black Hebrews obviously turn the reading of the Christian myth by their white ex-masters upside down, but they stay within the framework provided by Christianity. Black Muslims, whatever their correlation to orthodox Islam might be, have chosen not to accept the Christian myth. ${ }^{100}$ Interestingly, in both groups, we find the practice of acquiring a new name. In the NOI of Elijah Mohammad, we find a kind of rite of passage connected to this. The person is taken out from its old social definition (as a negro, a slave and so on), there is a liminal phase of being undefined (symbolized by the " $\mathrm{X}$ ") and finally, a new identity (social definition) as a kind of re-integration with a new role in the society is given to the "neophyte". ${ }^{101}$ This has already been pre-modelled in the teachings of Nobel Drew Ali and Wallace D. Fard. A renaming is also found among the leaders of the more radical Black Hebrews, as Ben Ammi or Yahweh Ben Yahweh. This quest to recover a lost true identity can also be found in the case of

\footnotetext{
99 E.g., Martin Luther King sought a different (integrationist) strategy.

100 Including the strategy of Elijah Muhammad mentioned above to give it a place within the timeframe of his own reconstruction of the history of mankind, as the period of the rule of the "white devils", preceded and followed by a time of black supremacy. 101 This is the structure of rites de passage as pointed out by van Gennep. On rites of passage see, e. g., Barnard / Spencer 1996.
} 
Walter King, who renamed himself as Adefunmi. ${ }^{102}$ It is important to see, that the English names substituted by Hebrew, "Moorish", Arabic or Yorùbá names are the names of the slaveholders that were the masters of the progenitors of the renamed individuals. So, African-American nationalist constructions of a new identity (involving genealogies that might seem strange at first view) respond to a need for a new identity. This need arises out of the situation of the AfricanAmerican as a wounded person, someone who is subjected to the dominion of the "Caucasians", someone whom human dignity is denied. The constructions of an ethnic identity discussed in this paper are constructions that deal with a situation of incongruence. There are many ways in which people can try to change such a situation, between accommodation and revolt. Gnosticism, e.g., could be interpreted as a response to a situation of incongruence. A situation of incongruence is characteristic of those groups that Max Weber has called "negatively privileged". ${ }^{103}$ Negatively privileged groups will have an inclination to a dualistic world-view. Without discussing different forms of dualism ${ }^{104}$ and abstaining from a discussion of the changing meanings the term "fundamentalism" has taken on since its invention as a self-description of anti-modernist evangelical white Christians in the USA, ${ }^{105}$ I refer to the characteristics of fundamentalism that Droogers mentions. ${ }^{106}$ In some stages of the development of the religions mentioned here we can detect what he calls a strong inclination to a dualistic world view with a clearly defined enemy, assertive (or aggressive) strategies, the leadership of charismatic persons, a strict code of behaviour, a literal understanding of sacred texts and a somehow "essentialist" understanding of religion. Some of the groups have softened this approach in the course of their development, with the striking example of NOI, in which the adaptation that took place after Elijah Muhammad's death by his son Wallace Muhammad led to a split with the group led by Louis Farrakhan staying with a literal understanding of the "white devil" and with dualistic enemy-thinking. As we have seen in the case of Amos Ben Ammi and Elijah Mohammad in their changing attitude towards orthodox Jews, and as we have seen in the split of NOI sketched above, in the interaction with the society at large, there is always a room to move between strict separatist (i.e. fundamentalist) and more integrationist strategies.

\footnotetext{
102 See footnote 9 above.

103 And that will therefore produce a religion of "salvation"; see Weber 1980, p. 298, pp. 300-302.

104 On different forms of “dualism” see Rudolph 1994, pp. 68-69.

105 See, e.g., Harwazinski 2005.

106 Droogers 2008, p. 53.
} 


\section{References}

Ali, Noble Drew: The Holy Koran of the Moorish Science Temple of America (no place or year indicated).

Anderson, Jeffrey Elton: "Hoodoo", in: Pinn 2009, pp. 197-200 (= Anderson 2009a).

Anderson, Jeffrey Elton: "Voodoo", in: Pinn 2009, pp. 427-439 (= Anderson 2009b).

Baer, Hans A. / Singer, Merrill: African-American Religions: Varieties of Protest and Accomodation. Knoxville 2002.

Barnard, Alan / Spencer, Jonathan: "Rite of Passage", in: id. (ed.): Encyclopaedia of Social and Cultural Anthropology. London / New York 2002, pp. 489-490.

Barrett, Leonard E.: The Rastafarians. Boston 1997.

Berg, Herbert: "Mythmaking in the African-American Muslim Context: The Moorish Science Temple, the Nation of Islam, and the American Society of Muslims", in: Journal of the American Academy of Religion (73) 2005, pp. 685-703.

Brandon, George: Santería from Africa to the New World: The Dead Sell Memories. Bloomington / Indianapolis 1997.

Brotz, Howard M.: The Black Jews of Harlem: Negro Nationalism and the Dilemma of Negro Leadership. New York ${ }^{2} 1970$.

Brown, David H.: Santería Enthroned: Art, Ritual, and Innovation in an Afro-Cuban Religion. Chicago / London 2003.

Carson, Clayborne: "The Unfinished Dialogue of Martin Luther King, Jr. and Malcolm X”, in: AH Magazine of History (19) 2005, pp. 22-26.

Chevannes, Barry: "Introducing the Native Religions of Jamaica", in: id. [ed.], Rastafari and Other African-Caribbean Worldviews. New Brunswick ${ }^{2} 1998$.

Chireau, Yvonne / Deutsch, Nathaniel (eds.): Black Zion: African-American Religious Encounters with Judaism. Oxford et al., 2000.

Chireau, Yvonne: "Black Culture and Black Zion: African-American Religious Encounters with Judaism, 1790-1930, an Overview", in: Chireau/Deutsch 2000, pp. 1533.

Clarke, Kamari Maxine: “Oyotunji African Village”, in: Pinn 2009, pp. 290-302.

Collins, Robert O. / Burns, James M: A History of Sub-Saharan Africa. New York ${ }^{2} 2014$.

Cone, James H.: The Spirituals and the Blues: An Interpretation. Maryknoll 1991.

Curtis, Edward E.: The Call of Bilal: Islam in the African Diaspora. Chapel Hill 2014.

Curtis, Edward E.: Black Muslim Religion in the Nation of Islam, 1960-1975. Chapel Hill 2006.

Curtis, Edward E.: Islam in Black America: Identity, Liberation, and Difference in African-American Islamic Thought. New York 2002.

De la Torre, Miguel A.: Santería: The Beliefs and Rituals of a Growing Religion in America. Grand Rapids 2004.

Desmangles, Leslie G.: "Vodou”, in: Glazier, Stephen D. (ed.): Encyclopaedia of African and African-American Religions. New York 2001, pp. 361-364.

Deutsch, Nathaniel: "The Proximate Other: The Nation of Islam and Judaism", in: Chireau/Deutsch 2000, pp. 91-117.

Droogers, André: "Syncretists, Fundamentalists and Scholars compared", in: Adogame, Afe / Echtler, Magnus / Vierke, Ulf (eds.): Unpacking the New: Critical Perspectives on Syncretization in Africa and Beyond. Wien / Berlin 2008, pp. 47-69. 
Easterling, Paul: "Black Hebrew Israelite Tradition”, in: Pinn 2009, pp.111-115 (= Easterling 2009a).

Easterling, Paul: “Moorish Science Temple of America, Inc.”, in: Pinn 2009, pp. 222-226 (= Easterling 2009b).

Fauset, Arthur Huff: Black Gods of the Metropolis: Negro Religious Cults of the Urban North. Philadelphia ${ }^{2} 2001$ (reprint of first edition of 1944 with a foreword by Barbara Dianne Savage).

Fernheimer, Janice W.: “Commandment Keepers of Harlem”, in: Pinn 2009, pp. 169-174.

Frazier, E. Franklin: The Negro Family in the United States. Chicago ${ }^{2} 1940$.

Fulop, Timothy E.: “'The Future Golden Day of the Race': Millenialism and Black Americans in the Nadir, 1877-1901", in: Fulop/Raboteau 1997, pp. 227-254.

Fulop, Timothy E. / Raboteau, Albert J. (eds.): African-American Religion: Interpretive Essays in History and Culture. New York / London 1997.

Hardy, Clarence E.: "From Exodus to Exile: Black Pentecostals, Migrating Pilgrims, and Imagined Internationalism", in: American Quarterly (59) 2007, pp. 737-757.

Harwazinski, Anna Maria: "Fundamentalismus / Rigorismus", in: Metzler Lexikon Religion: Gegenwart - Alltag - Medien. Band 1. Stuttgart / Weimar 2005, pp. 427-434.

Herskovits, Melville: The Myth of the Negro Past. New York / London 1941.

Hödl, Hans Gerald: "African Traditions Reshaped?: Discussing Models for Explaining Continuity and Change in Cuban Santería”, in: Kováč, Milan / Gál, Tomáš (eds): Religious Change. Bratislava 2010, pp. 141-148.

Hurston, Zora: "Hoodoo in America", in: The Journal of American Folklore (44) 1931, pp. 317-417.

Karade, Baba Ifá: The Handbook of Yoruba Religious Concepts. York Beach 1994.

Kidd, Thomas S.: The Great Awakening: The Roots of Evangelical Christianity in Colonial America. New Haven / London 2007.

Law, Robin: The Oyo Empire c. 1600 - c. 1836: A West African Imperialism in the Era of the Atlantic Slave Trade. Aldershot 1991 (reprint of first edition Oxford 1977).

Levine, Lawrence: "Slave Songs and Slave Consciousness: An Exploration in Neglected Sources", in: Fulop/Raboteau 1997, pp. 57-87.

Lincoln, C. Eric: The Black Muslims in America. Boston 1961.

Long, Carolyn Morrow: A New Orleans Voodoo Priest: The Legend and Reality of Marie Laveau. Gainsville et al. 2007.

Long, Carolyn Morrow: Spiritual Merchants: Religion, Magic, and Commerce. Knoxville 2001.

Lovejoy, Paul E.: Transformations in Slavery: A History of Slavery in Africa. New York ${ }^{3} 2013$.

MacRobert, Iain: “The Black Roots of Pentecostalism”, in: Fulop/Raboteau 1997, pp. 295-309.

Mamiya, Lawrence A.: “American Muslim Mission”, in: Pinn 2009, pp. 77-88 (= Mamiya 2009a).

Mamiya, Lawrence A.: "Nation of Islam”, in: Pinn 2009, pp. 239-252 (= Mamiya 2009b).

Michaeli, Ethan: “The Hebrew Israelites from Chicago to Dimona”, in: Chireau/Deutsch 2000, pp. 73-90. 
O’Connor, Kathleen Malone: "The Nubian Islaamic Hebrews, Ansaaru Allah Community: Jewish Teachings of an African American Muslim Community", in: Chireau/ Deutsch 2000, pp. 118-150.

Park, Robert E.: "The Conflict and Fusion of Cultures with Special Reference to the Negro", in: The Journal of Negro History (4) 1919, pp. 111-133.

Pinn, Anthony B. (ed.): African-American Religious Cultures. Santa Barbara / Denver / Oxford 2009.

Pinn, Anthony B.: "Church of the Living God, Pillar of Truth for All Nations", in: Pinn 2009, pp. 166-169 (= Pinn 2009a).

Pinn, Anthony B.: "Church of God and Saints of Christ", in: Pinn 2009, pp. 152-156 (= Pinn 2009b).

Pinn, Anthony B.: "Chronology of People and Events", in: Pinn 2009, pp. 615-636 (= Pinn 2009c).

Preston-Blier, Suzanne: African Vodun: Art. Psychology, and Power. Chicago / London 1995.

Raboteau, Albert J.: "African-Americans, Exodus, and the American Israel”; in: Johnson, Paul E. (ed.): African-American Christianity: Essays in History. Berkeley / Los Angeles / London 1994, pp. 1-17.

Raboteau, Albert J.: "The Black Experience in American Evangelicalism: The Meaning of Slavery", in: Fulop/Raboteau 1997, pp. 89-130.

Raboteau, Albert J.: Slave Religion: The "Invisible" Institution in the Antebellum South. Oxford et al. 1978.

Remus, Babette: "Sekte", in: Metzler Lexikon Religion: Gegenwart-Alltag - Medien. Band 3. Stuttgart / Weimar 2005, pp. 283-285.

Rudolph, Kurt: Die Gnosis: Wesen und Geschichte einer spätantiken Religion. Göttingen 1994.

Singer, Merrill: "Symbolic Identities in an African-American Religious Sect: The Black Hebrew Israelites", in: Chireau/Deutsch 2000, pp. 55-72.

Smith, R. Drew: "Black Religious Nationalism and the Politics of Transcendence", in: Journal of the American Academy of Religion (66) 1998, pp. 533-547.

Smith Omari-Tunkara, Michelle: Manipulating the Sacred: Yorùbá Art, Ritual, and Resistance in Brazilian Candomblé. Detroit 2005.

Stewart, C.C.: "Islam", in: Roberts, Andrew (ed.): The Cambridge History of Africa: Volume 7: From 1905 to 1940. Cambridge 1986, pp. 191-222.

Sulikowski, Ulrike: "Hollywoodzombie: Vodou and the Caribbean in Mainstream Cinema”, in: Kremser, Manfred (ed.): "Ay Bobo": Afro-Karibische Religionen. Teil 2: Voodoo. Wien 1996, pp. 77-96.

Thompson, Robert Farris: Flash of the Spirit: African \& Afro-American Art \& Philosophy. New York 1984.

Vincent, Theodor G.: Black Power and the Garvey Movement. Baltimore 2006 (reprint of first edition 1970).

Wallis, Roy: The Road to Total Freedom: A Sociological Analysis of Scientology. London 1976.

Weber, Max: Wirtschaft und Gesellschaft. Tübingen ${ }^{5} 1980$.

Wynia, Elly M.: Church of God and Saints of Christ: The Rise of Black Jews. New York 1998. 


\section{Internet-sources}

http://cogasoc.org/wordpress/locations [29.01.2016].

http://www.finalcall.com/artman/publish/Entertainment_News_5/article_9921.shtm [23.04.2016].

http://www.krsone.biz/temple_bio.html [29.01.2016].

http://www.nytimes.com/2015/01/01/world/middleeast/ben-ammi-ben-israel-leader-of-

black-americans-who-migrated-to-israel-dies-at-75.html?_r $=0$ [30.01.2016]. http://www.yahwehbenyahweh.com/ [30.01.2016]. 